\title{
Impact of Islamic Motives, Customer Profitability and Service Quality on Customer Satisfaction from Islamic Banks
}

\author{
ARSHAD KHAN \\ MS Scholar, University of Swabi, Pakistan \\ arshad.khan219ak@gmail.com \\ SAYYAM \\ Research Coordinator, Institute of Business Studies and Leadership, \\ Abdul Wali Khan University, Mardan, Pakistan \\ sayyam@awkum.edu.pk \\ ABDUR RAHMAN \\ PhD Scholar, Institute of Business Studies and Leadership, \\ Abdul Wali Khan University, Mardan, Pakistan \\ mngrpk@gmail.com
}

\begin{abstract}
Success of any Islamic banks greatly depends on consumers, so Islamic banks need to create ethical environment, where perception of Islamic banks are carefully developed. The persistence of this is explained the nature and pervasiveness of Islamic banking and to pinpoint the linkage between consumer's satisfaction and banks performance in Pakistani Islamic banks. And also make out that customer preferred Islamic banks. Islamic banks sector was selected for the research, In order to obtain the required objectives, From Meezan bank and Bank Islami, Nowshera we selected 137customer's, and data was collected from them through a well-designed questionnaire. SPSS (17.0) were used for analyze togetherthe data. The Cranach's Alpha $(\alpha)$ Reliability methods were used to test the reliability of data. Findings exposed that there was significant and up relationship of ISLAMIC banks performance with customer's satisfaction. So Islamic bank is strong predictor of customer's fulfillment and determination of C'S depends upon on the Islamic banks performance of relationship.
\end{abstract}

Key words: Islamic banking, Islamic motive, Service quality, Profitability, Customer satisfaction.

\section{Introduction}

The development of the today's era financial system is much dependent in the financial institution performance. In the financial institutions which consist of insurance company and banks are contributing greatlythe economic development of a country. Financial services are being recognized as one of the building blocks of development. Commercial banks are working since a long time and provide financial services all around the world but are being criticized for safeguarding the interests of its shareholders and managers only rather than their customers (Bateman, 2010). In the growth of Islamic banks method is prior, conventional banks were thought to be the main ingredient in the 
development of the economy. These days world is facing economic problem in large scale. According to one of the great Pakistani scholar Mufti TaqiUsmani said that, "the world waspoorly in meets of third economic system. The Muslims can work on it Quran \& Prophet Muhammad (SAW) Sunah is quite capable of solving all the economically problems as these days faced by this world it's just because of capitalism (the more you will work the great you will earn) and capitalism is the between the just and unjust earning. (Imran ,2011).

Recent studies have shown that Islamic banking serve for great development in the economy. Islamic banking is becoming popular as well as has a boundlessprospective of growth in Pakistan (Bhutto,2013). Alternative other banks, Islamic banking system has been considered as better by many researchers because it caters the needs of all the participants rather than just of its shareholders and the situationalso focus in the principle of Islamic sharia laws. Factors and objectives that distinguish between these banks are Riba and risk involvement practices. The motive of Islamic banking is to promote businesses by enhancing the system of borrowing and lending coupled with the consideration of religious factors. The system of IB is truly based on the principal of equity and balance. IB promotes trade and sharpens the process of development in a sense of more engaging in the management of capital goods rather just for earning the increase or excess on the funds being lent to others.

The profit earned by IB is not fixed rather it depends on the management of capital goods. IB utilizes the funds in a better way because it tries to achieve greater economies of scales. Profit and loss sharingone of the main concepts of IB system, based on this the whole IB system is revolving. Unlike conventional Banking system which are operating to achieve profit in the form of interest and which literally doesn't try to make greater contribution to the economy, by that way economies of scale is a very far concept. CB is also against the rule of lord (Ahmad et al. 2010). Islamic banks use different types of Islamic modes of financing. Mudarabah and Musharakah are the popular of them. The Holy Prophet Hazrat Muhammad (Peace Be upon Him) also practiced himselfMudarabah transaction to sign the agreement with Hazrat Khadija (May Allah is pleased with her). On the basis of this agreement many people of are following Mudarabah agreements all over the world. Large numbers of Muslims are using Musharakah base agreement in their businesses and financial activities. Islam in the early days theevery religion and opponents Islam were also deposited their valuable things with the Prophet Muhammad (Peace Be upon Him) and Abu Bakar (May Allah be pleased with him) trust main basic thing which were the type of banks activities. In the competition between IB and CB is very severing. Banking is constantly determined to attract addedthe customers. Both banks are trying to provide better services to the customers to make enough profit and stay. The banks delivering quality services according to realize more profits for customer expectations. (Ashfaq Ahmad et al 2010). Focusing of Islamic banks not only to attract the existing customer, but is in constant pace to attract more customers for making more contribution to the economy as whole (Barathy Doraisamy 2011).

\section{Theoretical Background and Literature Review} 2.1 Customer Satisfaction

C'S who buying the goods and services delivered by enterprises or companies to customer. In other domain, for organization the customer is also added in the stakeholder 
foam that provide the payments in give-and-take offer delivered him by the organization to fulfill the need and take full advantage to the satisfaction. At the timeconsumer and customer were baffling. Customer are consumer, the consumer may not essentially be a customer. Many author is explained there difference. I.e. the customer were buying the product and the consumer is consume ultimately the product's (Solomon, 2009)

The expectations of their product outcome the satisfy consumer give the result of comparing the product's (Kotler\& Keller, 2009). The group of people or another person that were used the good and services could give the satisfaction of product and delivered. The satisfaction is various from one individual to another person for its utility.so for the highlighting of the customer satisfaction it's very difficult to satisfied everyone or to conclude satisfaction surrounded by group of specific. Happiness of the customer, which were used the CS, and itsutmostvital for every organization toward determine the customer needed. C'S defined by one author that the consumption of good and services the consumer give the response of the product between rear expectation and tangible performance (Tse\& Wilton, 1988). Therefore allowing for fulfillment as thetotal postbuying assessment by the consumer (Fornell, 1992). Many author not give the verifying definition of CS, after this studies many definition they defined CS as "CS is identify by a response (perceptive or moving) that connect to particular focus (i.e. a buying experience / linking with product) and happen at a certain time (i.e. post-buying, postconsumptions)". (Giese \& Cote, 2000)

\subsection{Service Quality}

In SQ company offering to touch the customer there a basic want for services. The various organizations differ in the types of product that depend on the services. Services could be defined many ways that depended on which place that being used. Author defined services as "any immaterial act or performance one group offering to another group that dint not result in the ownership of something" (Kotler\& Keller, 2009). In all, it tangible offer by one group to another in exchange of money for desire. The consumer look in the offering that one of the thing in the quality, that which offer is good for services to be happen. (Solomon, 2009). The quality defined in the totality of physical appearance and features of a product and services that stand on it's able to satisfy listed or implied their needs. (Kotler et al, 2002). For the value of offering the quality is also related for services, which could suggest the satisfaction or dissatisfaction in the amount on user (Zeithaml et al, 1990) (Bowen et al, 2005). The organization which fare good are poor that service quality aim to be the way in which customer are served. One other author defined that services quality as "the perception of services the difference between customer expectation" (Parasuraman, 1988). They argued mean SQ as the difference between apparent and likely service it was a valid way and could make management to identify gaps to what offer in services

Hypothesis 1.There is a positive relation between service quality and consumer satisfaction.

\subsection{Islamic Motives}

The IM in Islamic banks the banking products the customers are not wide-awake, the Muslim customers in many number that open the account in the Islamic banks only in religion belief (Omer, 1992), (Erol et al, 1989) in this research that the religion is not important fact for selection the Islamic banks. The Muslim people can be trusted in the 
IB on the belief and based without know and information detail of IB service and there product and vice versa. In the IB toward the sharia compliance and convenience are the motivating factors the guiding the research from performance of IB and CB in Pakistan (Hanif, 2012). The customer not used only for the product and service of the goodness but it's take up and accept free banking logo. (Sehrish et al, 2011) in the study of CC toward IB added the religion and give the financial benefit and it is important line draw for select Islamic bank (Almossawi, et, al 1998). In the Bahrain the IB existing purely belief and rate of return that two factor giving priority to IB by the CC. However (Usman, et al 2015) give reported that religion and responsive fact not only motives of customer toward IB.

Hypothesis 2. There is a positive relation between Islamic motive and consumer

\subsection{Customer Profitability}

\section{satisfaction.}

In the $\mathrm{CP}$ is a level of customer variable refers to the returns that less expenditures which one specific customer makes in set period of time. As such as, one of these particular customer variables refers to the supplier's value. $\mathrm{CP}$ in marketing related literature has two appear temporal forms. First, it appears as a matter of historical recorded. In this sense, a CP analysis is alike to the firm's profit and loss acknowledgment. CP investigation alludes primary distinction to one specific client, while a benefits and misfortune alludes every one of the clients' announcement. A history arranged $\mathrm{CP}$ investigation made it a few dimensions. A primary concern of withdrawal is to ascertain the edge commitment (net commitment edge), for example deals salary less the items related costs for all items sold to and the individual client during timespan of the one specific (Wang, 1994). It's relied upon the information accessibility, regulatory costs and general recognizable to the one client are subtracted (Cooper, 1990).

The "customer return on assets" is an extension of this calculation is the operating profits generated by the customer. I.e. CP is divided by e.g. the sum of inventory and account receivables (Rust et al, 1996). Second, CP is also referring the future sense in literature. In this case, the net present value analysis from output its takes often in this form. The "lift time value" the output is some time shows of the customer (Heskett et al, 1997). It has defined, e.g. as the stream of assume future profits, on a customer's transaction, gross of costs, discounted at some current net present value appropriate rate back. (Peppers et al, 1997). Alike concept is "customer equity" which is seen a function of the margin per units of purchase, customer's volume of purchases, development and retention costs traceable and acquisition to this customer (Blattberg et al, 1996).

Hypothesis 3. There is a positive relation between profitability and consumer satisfaction. 


\subsection{Theoretical Framework}

Following theoretical framework has been developed for the generation of hypothesis (Figure 1).

\section{Figure no.l conceptual framework}
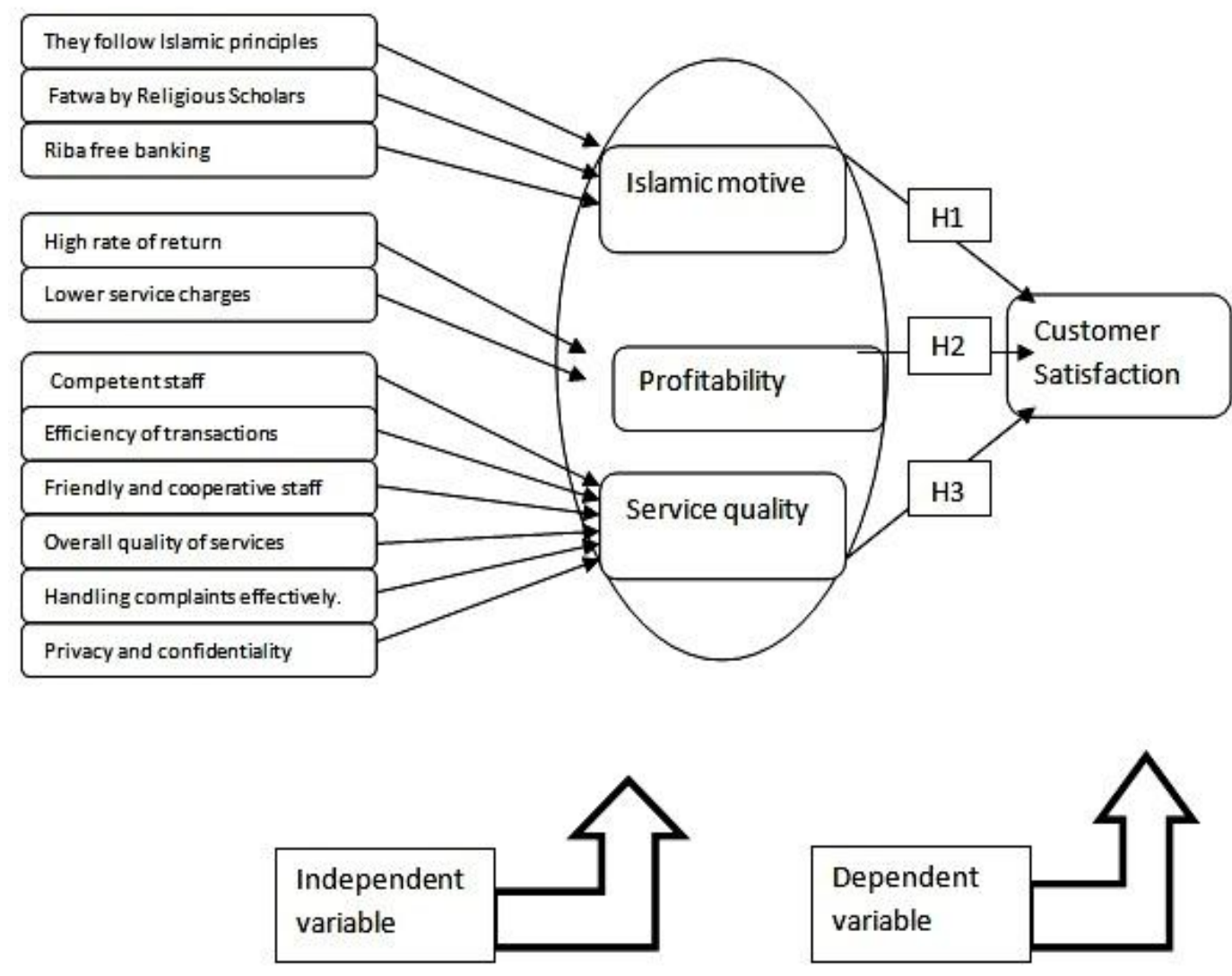

\section{Research Methodology}

This study is inclined to collect data from both the customers of Meezan Bank Limited and Bank Islami Limited in Nowshera region. This study was qualitative in nature, conducted through a survey questionnaire. The constructs of this study questionnaire adopted from many studies. The five likert scales were used in this questionnaire with 1 to 5 ratings. Theconvenience sampling techniquewas selected for collecting the sample size. 170 respondents were selected to get the response for the study. The response rate was $100 \%$ as all of the respondents had fully and responsibly filled the questionnaire. Data was analyzed through SPSS. Data analysis techniques used were Demographic, Correlation, Reliability and Regression analysis. 


\section{Results and Discussion}

Table 1: Demographic Analysis

\begin{tabular}{lllll}
\hline & & Gender & \\
\hline & Frequency & Percent & Valid Percent & Cumulative Percent \\
Male & 115 & 87.8 & 87.8 & 87.8 \\
Female & 16 & 12.2 & 12.2 & 100.0 \\
Total & 131 & 100.0 & 100.0 & \\
Age & & & & \\
& Frequency & Percent & Valid Percent & Cumulative Percent \\
Less than 26 years & 20 & 15.3 & 15.3 & 15.3 \\
26-36 years & 58 & 44.3 & 44.3 & 59.5 \\
37-46 years & 25 & 19.1 & 19.1 & 78.6 \\
Above 46 years & 28 & 21.4 & 21.4 & 100.0 \\
Total & 131 & 100.0 & 100.0 & \\
Income level & & & & \\
& Frequency & Percent & Valid Percent & Cumulative Percent \\
Rs:-6000-11,000 & 4 & 3.1 & 3.1 & 3.1 \\
Rs:- 12,000-21,000 & 12 & 9.2 & 9.2 & 12.2 \\
Rs:- 22,000-31,000 & 40 & 30.5 & 30.5 & 42.7 \\
Rs:- 32,000-41,000 & 44 & 33.6 & 33.6 & 76.3 \\
Rs:- Above 41,000 & 31 & 23.7 & 23.7 & 100.0 \\
Total & 131 & 100.0 & 100.0 & \\
Qualification & & & & \\
& Frequency & Percent & Valid Percent & Cumulative Percent \\
SSC/ O-level & 7 & 5.3 & 5.3 & 5.3 \\
HSSC/ F.A/ F.SC & 28 & 21.4 & 21.4 & 26.7 \\
BA/B.Sc. 14year & 53 & 40.5 & 40.5 & 67.2 \\
Masters/Equivalent & 32 & 24.4 & 24.4 & 91.6 \\
MS/PhD & 11 & 8.4 & 8.4 & 100.0 \\
Total & 131 & 100.0 & 100.0 & \\
\hline \multicolumn{1}{l}{ The result of } & & & \\
\hline
\end{tabular}

The result of demographic profile of Islamic bank customers inNowshera showed in the table 1 which includes the detail about Gender, Age, Income level and academic qualifications of customers. We find that maximumof IB customers were male and the ratio of female is very low as compare to male customers. The age of Islamic bank customers shown in table 4.1, majority of customers were in the age of 26 to 36 with a percentage 44.3 . The age of more than 46 was $21.4 \%$ which is the second large population of Islamic bank in Nowshera. 19\% of the customers were in between 37-46 and the ratio of less than 26 years was only $15 \%$. Islamic banks should also focus on the youth they should offer different kinds of packages, facilities, scholarships and business 
opportunities to run the awareness and quality campaign in colleges, institutions and universities no doubt youth is the main power of any sector in every country. The Income level of Islamic bank customers were divided into groups and it is based on an average monthly income because in the Pakistan maximum people received and calculate their income on the monthly basis. The result in table 4.1 illustrations us that the percentage of 32,000 to 41,000 is high which is $33.6 \%$ while $30.5 \%$ of customers having the income of 22,000 to 31,000 and $23.7 \%$ of customers have the income of more than 41,000 and $9.2 \%$ customers belong to the group of income level between 12000 to 21000 and in last the $3.5 \%$ customer falls into income level of 6000 to 11000 . After the income overview of Islamic bank customers table 1 involves the qualification detail of Islamic bank customers in Nowshera region shows us that greatest of the IB customers are highly qualified only 5.03 percent of customers are fall into the group of SSC or equivalent the remaining 40.5 percent are graduate or equivalent, 24.4\% are Masters, and 8.4 percent of the customers having the qualification of $\mathrm{MS} / \mathrm{PhD}$.

Table 2: Reliability-Statistics

\begin{tabular}{cc}
\hline N of item & Cronbach's Alpha \\
\hline 17 & .705 \\
\hline
\end{tabular}

Reliability of the study constructs are obtained through Reliability analysis using Cronbach's Alpha. Table 2 shows the constructs of reliability is above 0.7 which shows a very good range. It is mentioned in the study that Cronbach's alpha greater than 0.7 shows an acceptable range.

Table 3: Correlations Analysis

\begin{tabular}{|c|c|c|c|c|}
\hline & IM & PB & SQ & $\mathrm{CS}$ \\
\hline IMPearson correlation & 1 & $.512^{* * 4}$ & $.647^{* *}$ & $.821^{* * 4}$ \\
\hline \multirow{2}{*}{$\begin{array}{l}\text { Sig. (2-tailed) } \\
\mathrm{N}\end{array}$} & & .000 & .000 & .000 \\
\hline & 131 & 131 & 131 & 131 \\
\hline PB Pearson correlation & $.512^{* *}$ & 1 & $.329^{* *}$ & $.769^{* *}$ \\
\hline Sig. (2-tailed) & .000 & & .000 & .000 \\
\hline $\mathrm{N}$ & 131 & 131 & 131 & 131 \\
\hline SQ Pearson correlation & $.647^{* *}$ & $.329^{* *}$ & 1 & $.694^{* *}$ \\
\hline Sig. (2-tailed) & .000 & .000 & & .000 \\
\hline $\mathrm{N}$ & 131 & 131 & 131 & 131 \\
\hline CS Pearson correlation & $.821^{* *}$ & $.769^{* *}$ & $.694^{* *}$ & 1 \\
\hline Sig. (2-tailed) & .000 & .000 & .000 & \\
\hline $\mathrm{N}$ & 131 & 131 & 131 & 131 \\
\hline
\end{tabular}

\footnotetext{
** Correlation level at the significant level 0.01 (2-tailed).
} 
Table 3 shows the association of IVorDV. It also explains the strength of the connection between the variables. The above table shows Islamic motive correlation with customer satisfaction is.82 ${ }^{* *}$ with .000 level of significance. According to correlation assumptions if $p$ value is less than .001 then correlation is considered to be significant. However if the Pearson's correlation value is above.04 it is in an acceptable range. The Pearson's correlation value specifies the strength of the relation which in this case is $.821^{* * *}$ with $p<.001$ which means the results are statistically significant i.e. there is a strong relationship between Islamic motive and customer satisfaction. The PB correlation with customer satisfaction is $.769^{* *}$ with $p<.001$ which is also statistically significant i.e. there is a strong relationship between PB and customer satisfaction with Islamic banks. Service quality correlation with customer satisfaction is $.697^{* *}$ with $p<.001$ which is also statistically significant i.e. there is a strong association between SQ and CS.

\section{Table 4:Model Summary}

\begin{tabular}{ccccc}
\hline Model & R & R Square & $\begin{array}{c}\text { Adjusted R } \\
\text { Square }\end{array}$ & $\begin{array}{c}\text { Std. Error of } \\
\text { the Estimate }\end{array}$ \\
\hline 1 & $.941^{\mathrm{a}}$ & .885 & .883 & .08578
\end{tabular}

a. Predictors: (Constant), SQ, PB, IM

The above table 4 shows $\mathrm{R}$ value which is .941 shows dependent variable prediction quality. In this case $\mathrm{R}=.941$ shows a good prediction level. The $\mathrm{R}$ Square in second column value is .885 that confirmations proportion of variance in the dependent variable affected by the dependent variable. Adjusted R Squares that is .883 it good accept range. This clarifies $88 \%$ variation is affectedIV.

\section{Table 5:ANOVA ${ }^{b}$}

\begin{tabular}{ccccccc}
\hline & & Sum of & & & & \\
& Model & Squares & df & Mean Square & F & Sig. \\
\hline 1 & Regression & 7.221 & 3 & 2.407 & 327.140 & $.000^{\mathrm{a}}$ \\
& Residual & .934 & 127 & .007 & & \\
& Total & 8.156 & 130 & & & \\
& & &
\end{tabular}

\section{a. Predictors: (Constant), SQ, PB, IM}

b. Dependent Variable: CS

The table 5 ANOVA gives the fitness and significance of statistical data in this model. In this table $\mathrm{F}(3,127)=327.140$ and $\mathrm{p}<.005$ show the fitness of the data in regression model and the IV are good and its significant predict in the DV i.e. CS with IB is significantly founded by Islamic motive, PB or Service quality. 
Table 6:Coefficient

\begin{tabular}{ccccccc}
\hline & & \multicolumn{2}{c}{$\begin{array}{c}\text { Unstandardized } \\
\text { Coefficients }\end{array}$} & \multicolumn{2}{c}{$\begin{array}{c}\text { Standardized } \\
\text { Coefficients }\end{array}$} & \\
& Model & B & Std. Error & Beta & t & Sig. \\
\hline 1 & (Constant) & .301 & .148 & & 2.029 & .045 \\
& IM & .354 & .039 & .396 & 9.139 & .000 \\
& PB & .272 & .020 & .474 & 13.560 & .000 \\
& SQ & .310 & .043 & .282 & 7.155 & .000 \\
\hline
\end{tabular}

a. Dependent Variable: CS

Table 6 refer the strong point of the association of each of the IV with DV.in this table Islamic motives Beta is .354 with matching value 9.139 and significance value of p $<05$ is significantits means if the 1 units or $1 \%$ increase in Islamic motives so then CS will be increased value by 0.354 units or $35.4 \%$ Similarly profitability value of Beta is .272 with matching $t$ value 13.560 and significance value $p<05$ is statistically significance which means if 1 unit or $1 \%$ increase in profitability will increase .272 units or $27.2 \%$ in Consumer satisfaction, similarly unstandardized "B" for service quality is .310 units or $31 \%$ with corresponding $t$ value 7.155 which means that one unit or $1 \%$ increase in service quality will increase .310 units or $31 \%$ in Consumer satisfaction. "P" value is less than 0.05 or $5 \%(\mathrm{P}<0.05)$ so model is held to be good. The results indicated there is significant positive association between customer satisfaction and all three IV, Islamic motive, Profitability and service quality consequently hypothesis " $\mathrm{H} 1, \mathrm{H} 2, \mathrm{H} 3$ " are supported.

\subsection{Discussion}

In the primitive stage of Islamic banking evolution people would deposit their precious metal and excess money with the persons of highest degree of honesty and credibility; charging interest on borrowed money has been a legitimate business for centuries. Later religious sentimental worlds took initiative to dismantle the curse of charging interest on funds and have deployed a classical view of Sharia law. The purpose of savings in the shapes of deposit is not just safekeeping but generating profit for the customer without interest. Result which is achieved from the survey of IB show is helpful in nature. . Practically customers divert to IB practices due at sole the IB services are in accordance with Islamic Sharia. Customer uses Islamic banking because Islamic banks follow as Islamic principle.The theme of IB is constructed on the divine testament of Quran and Hadith of the Holy Prophet (PBUH) and has extracted its origin from the Quran and Hadith. Similar in fashion like conventional bank Islamic banks provides the best of services and has been the main ingredient of the Islamic economic system.

Customers go for availing the services of any bank either Islamic or conventional are based on the type of services offered by the banks. Customer perceive and judge the degree of best services based on the dealing with the banks internal staff, communication with , showing respect for the customer and mutual trust. Studies found a relationship between the services are offered by the bank consideration of bank physical environment and areas adjacent with, its pollution free, and facilitation in the process of providing services like ATM etc. intact leads to customer satisfaction. 


\subsection{Conclusion}

This study identifies important findings regarding relationship between Islamic motive, customer profitability, quality of service and consumer satisfaction. It was found that Islamic banking has a positive impact on consumer satisfaction. It explains that consumers are more satisfy from the IB. The results of descriptive analysis explain in the Pakistan context that religion is the first priority in the primary motives of IB. The study support previous studies. The result indicate there is positive and significant association between IB i.e. Islamic motive, profitability, SQ and overall CS, and customers who perceive Islamic banking, they are more satisfied. So in order to increase positive attitudes and behaviors like consumer satisfaction, efforts must be made by Islamic banking to improve the consumer satisfaction system because satisfied and committed consumer show more efficiency and may also increase the Islamic banking productivity. In all the finding should improve that IB their quality of services as well as to improve responsiveness and give understanding about products and services it may influence the customers' criteria of selecting an Islamic bank. he empirical investigation of the study provides several theoretical insights. First it provides the evidence that Islamic motives and service quality are the primary drivers of consumer's satisfaction. Second there is a relatively less role of profitability building of the Islamic banking in driving consumers' satisfaction.

\subsection{Future Research Direction}

In the future direction the research are more demanding and take up the direction to be analyzing the moderation and mediation role on the CS from Islamic banks. The future research has endedin thejudgment of how to Islamic banks Maximize the CS and how to be increased acceptability the IB in Muslim and Non-Muslim Communities.

\section{References}

Abdul, A. A. R. S. (2012). Perception of Non-Muslims Customers towards Islamic Banks in Malaysia. International Journal of Business and Social Science, Vol. 3(11), 151-163.

Ahmad, N. A. (2002). Perceptions of Malaysian corporate customers towards Islamic banking products and services. International Journal of Islamic Financial Services, 3(4), 13-29.

Ali, F. (2011). customer satisfaction and islamic banking in pakistan. international journational of asian social science, 89-96.

Sohail, A. M. F. (2014). Perception of Individual Consumers toward Islamic Banking Products and services in Pakistan. Journal of Poverty, Investment and Development, Vol. 05, 179-185.

Anwar, M. T. (2012). Measuring Customers Loyalty of Islamic Banking in Bahawalpur Region. International Journal of Learning \& Development, Vol. 2(2), 101-111.

Ashfaq, A. K. -U.-R. (2010). islamic banking experience of pakistan:comparision between islamic and conventional bank. international jouranal of business and management, vol.5(2), 137-143.

Ashfaq, A., K.-U.-R. I. (2010). An empirical investigation of Islamic banking in Pakistan based on perception of service quality. African Journal of Business Management., Vol. 4(6), 1185-1193. 
Azhar, A. G. (2014). consumer behaviour towards islamic banking in pakistan. European Journal of Accounting Auditing and Finance Research, Vol.2, No.9, 42-65.

Barathy, D. A. S. (2011). a study on consumers' perferences of islamic banking products and services in sungai petani. Academic Research International, vol. 1(3), 290-302.

Bashir, M. S. (2012). analysis of customer satisfaction with the islamic banking sector:case of bronei darussalam. asian journal of business and management sciences, vol. 2(10), 38-50.

Bhutto, I. U. (2013). An Empirical Investigation on Perception of Post-Graduate Students towards Islamic Finance in Islamic Republic Of Pakistan. Asian Journal of Research in Banking and Finance, Vol. 3, No. 12, 68-80.

Afsar, B. Z. U. ( 2010). Determinants of customer loyalty in the banking sector. African Journal of Business Management, 1040-1047.

Blattberg R. C. \&Deighton, J.(1996). Manage Marketing by the Customer Equity Test, Harvard Business Review, July-August, 136-144.

Cooper, R.\& Kaplan, R. S.(1991). Profit Priorities from Activity-Based Costing, Harvard Business Review, May-June, 130-135.

El-Bdour, E. A. (1990). Conventional and Islamic Bank: Patronage Behavior of Jordanian. International Journal of Bank Marketing, 8 (5) .

Erol C, E.-B. R. (1989). Attitude, behaviors and patronage factors of bank customers towards islamic banks. International Journal of Bank Marketing, 7(6), 7-31.

Erol, Kaynak\& El-Bdour, (1990). Conventional and Islamic Bank: Patronage behavior of Jordanian, International Journal of Bank Marketing.

Evangelos, G.\&Yannis, S. (2010). Customer Satisfaction Evaluation: Methods for Measuring and Implementing Service Quality. London: Springer.

Fornell, C. (1992). A National Customer Satisfaction Barometer: The Swedish Experience. Journal of Marketing, Vol. 56, p.6-21.

Hanif, M. T.U.M. (2012). Comparative Performance Study of Conventional and Islamic banks in Pakistan. International Research Journal of Finance and Economics, issue. 83, 63-72.

Hanif, (2012). Comparitive Performance Study of Conventional and Islamic Banks in Pakistan, International Research Journal of Finance and Economics, Issue 83, 63-72.

Heskett, J. L., Sasser, W. E. \& Schlesinger, L. A. (1997). The Service Profit Chain, The Free Press, New York.

Howell, R. A.\&Soucy, S. R.(1990). Customer Profitability: As Critical as Product Profitability, Management Accounting, October, 43-47.

Imran, S. (2011). Awareness Level of Islamic Banking in Pakistan's Two Largest Cities. Journal of Managerial Sciences, Volume 5(1), 01-20.

Isa, M. A. (2008). An examination of the relationship between service quality perception and customer satisfaction. international journal of islamic and middle eastern finance and management, vol.1(3), 191-209. 
Khan, M. S. (2008). banking bahavior of islamic customer in Bangladesh. journal of islamic economics, Banking and finance .

Kotler, P. \& Keller, K. L. (2009).Marketing management (13th end). New Jersey: Pearson Education Inc, Upper Saddle River.

Kotler P., Armstrong, G., Saunders, J. \&Wong V. (2002).Principle of Marketing, 3rd edition, Pretence Hall \$Europe.

Mehrdad, E. F. H. (2011). Determinants of customer satisfaction in Islamic banking:evidence from Iran. International Journal of Islamic and Middle Eastern Finance and management, Vol. 4 No. 4, 295-307.

Metawa, S. A. M. (1998). Banking Behavior of Islamic Bank customers:Perpectines and implication. international journal of marketing, 16, 299-315.

Metawa, S. A.\&Almossawi, M. (1998). Banking behaviour of Islamic bank customers: Perspectives and implications. International Journal of Bank Marketing, 16(7), 299313

Micheal, R. S. (2009). Consumer behaviour, Buying, Having and Being, 8th edition, Pearson education, inc.

Muhamad, A. S. K. (2012). Customer Satisfaction and Switching Behavior in Islamic Banking: Evidence from Indonesia. School of Doctoral Studies (European Union) Journal , 209-215.

Omer, H. (1992). The Implications of Islamic beliefs and Practice on Islamic Financial Institutions in UK. PhD Dissertation, Loughborough University, Loughborough.

Parasuraman, A., Zeithaml, V. A., \& Berry, L. L. (1988). SERVQUAL: A multiple-item scale for measuring consumer perceptions of service quality, Journal of Retailing, 64 (1), p.12-40.

Peppers, D.\& Rogers, M.(1993). The One-To-One Future, Piatkus, London.

Peppers, D.\& Rogers, M.(1997).Enterprise One to One, Dobleday, New York.

Rust, R. T.,Zahorik, A. J. \&Keiningham, T. L.(1996).Service Marketing, HarperCollins, New York.

Shtayyeh, S. (2008). introduction of islamic finance its Concepts, Models, Growth and opportunities.

Schiffman, L. G. \&LazarKanuk, L. (2004).Consumer Behaviour.8th edition. New Jersey Pearson Education Inc, Upper Saddle RiverTitus.

Sehrish, R. (2011). Perception of Corporate Customer towards Islamic Banking Products and Services in Pakistan, The Romanian Economic Journal, 107-123.

Tse, D. K. (1988). Models of consumer satisfaction formation: An extension. Journal of markering Research, 25, 204-212.

Usman, H. (2015). Comparison of the Importance of Bank Attributes between Islamic and Conventional Bank Customers, East Asian Journal of Business Management, Vol.5(2), 5-13.

Worthington, A. G. (2008). An empirical survey of individual consumer, business firm and financial institution attitudes towards Islamic methods of finance. international journal of social economics, Vol. 35(11), 783-808

Yi, Y. (1990). A critical review of consumer satisfaction, in Zeithaml, V.(Eds), Review of Marketing, American Marketing Association, Chicago, IL, p.68-123. 
Wang, P. \&Splegel, T.(1994). Database Marketing and Its Measurements of Success, Journal of Direct Marketing, Vol. 8(2), Spring, 73-84

Wayland, R. E \& Cole, P.M.(1997). Customer Connections: New Strategies for Growth, Harvard Business School Press, Boston, Massachusetts 